Jap. J. Human Genet. 23, 1-7, 1978

\title{
TRANSFERRIN VARIANTS IN KOREA AND JAPAN
}

\author{
Robert L. KirK,* Hideo Matsumoto, ${ }^{* *}$ and Kazumichi KataYAMA** \\ *Department of Human Biology, John Curtin School of Medical Research, Canberra, Australia, \\ **Department of Legal Medicine, Osaka Medical School, Takatsuki, Osaka, Japan
}

Summary Several transferrin variants detected in surveys of serum samples from Koreans and Japanese have been compared critically with standards and with each other using thin layer agarose gel electrophoresis and polyacrylamide gel electrophoresis.

All slow-moving variants were found to have identical mobility with a reference sample of $\mathrm{CD}_{\mathrm{Chj}}$. Four different fast-moving variants were detected, $\mathrm{B}_{\mathrm{Kore \varepsilon}}$, $\mathrm{B}_{\mathrm{Korea}}{ }_{2}, \mathrm{~B}_{\text {Jap. } 1}$ and $\mathrm{B}_{\text {Jap. 2. }}$. Their relative mobilities at pH 8.9 and 6.5 have been listed and compared with variants described by other investigators.

\section{INTRODUCTION}

More than 20 different electrophoretic variants of the iron-binding protein, transferrin, have been detected in human serum from many parts of the world (Kirk, 1968; Giblett, 1969; Sutton and Jamieson, 1972). Among these populations the Japanese seem to have an unusual number of transferrin variants. The present report provides further evidence for the variability of transferrin in Japan, and extends the survey to Korea.

The surveys carried out in Japan up to 1973 have been summarized by Omoto (1975). Not all the variants noted have been examined critically against known standards but the general results were:

1. The commonest variant is $D_{\mathrm{Chi}}$, the heterozygote frequency reaching 3.00 per cent among the Ainu and 1.75 per cent among the non-Ainu in Hokkaido. $\mathrm{CD}_{\mathrm{Ch}}$ has been found with frequency of 1.90 per cent in Mie Prefecture and 1.22 per cent on Amami Oshima Is. in Kagoshima Prefecture. Slow moving variants have been found in all other surveys but not identified as to type.

2. Fast moving $B$ variants were reported also in all but two of the surveys, the highest heterozygote frequency of 1.27 per cent being reported from Mie Prefecture. In some of the surveys the types were identified as $B_{1}$ in the Ainu, $B_{1}$ and $B_{3}$ in Japanese in Hokkaido and $B_{1}$ and $B_{3}$ in Mie Prefecture. The $B_{1}$ variant was first described in England by Harris et al. (1958) and the identification of the Japanese variants 
as $\mathrm{B}_{1}$ is almost certainly incorrect, a point which will be discussed in greater detail below. The $B_{3}$ had been described in a Japanese from Ube by Parker and Bearn (1961).

In a recent paper Ferrell et al. (1977) have reported 8 different transferrin variants in a total of 4,020 persons tested in Hiroshima and Nagasaki. Five of these variants were $D$ types, and three were $B$ types, faster moving than the normal $C$.

Clearly there is a relatively large number of transferrin variants in the Japanese population. It is important to describe these accurately in various parts of the country and in neighboring populations. The present paper describes the results for further studies and describes a test system using thin layer agarose gels for assisting in the identification of transferrin variants.

\section{MATERIALS AND METHODS}

1. Source of samples. The Korean samples used for the analysis were aliquots of samples from a total of 487 serum samples of unrelated individuals living in Seoul, South Korea. These slow and fast variants of transferrin were observed in addition to the common type, $\mathrm{Tf} \mathrm{C}$, which had a frequency of $98.15 \%$. The blood specimens were generously provided by Dr. T. Araki. Two slow and two fast variants of transferrin from Japanese were found among the 240 students in Osaka Medical School.

2. Thin layer agarose gel electrophoresis. Thin layer gels are prepared on glass plates $(15 \times 17 \mathrm{~cm})$ using $30 \mathrm{ml}$ per plate of 1 per cent Agarose (Type 11, Sigma Chemical Co.) in Tris-glycine buffer, $\mathrm{pH} 8.9$ (11.6 $\mathrm{g}$ Tris and $3.7 \mathrm{~g}$ glycine to 1 litre distilled water). The plates are precoated with a 1.0 per cent solution of agarose in water and allowed to dry.

Slots are cut into the gel $3 \mathrm{~cm}$ from the cathodal end using a perspex former $1 \mathrm{~mm}$ thick, and $1 \mu \mathrm{l}$ of serum applied to each well using a micropipette. The plates are electrophoresed horizontally on metal cooling plates at approximately $10^{\circ} \mathrm{C}$ using Whatman No. $3 \mathrm{MM}$ filter paper as wicks and the Tris-glycine buffer $\mathrm{pH} 8.9$ in the electrode vessels with a voltage gradient of $10.0 \mathrm{v} / \mathrm{cm}$.

After electrophoresis the plates are stained with Coomassie Blue $(0.2$ per cent in methanol, acetic acid, water-9:2:9) and destained in a detergent solution (2.5 per cent acetic acid, $2.5 \%$ Teepol in water).

3. Vertical acrylamide gel electrophoresis. The method is essentially that of Sutton and Jamieson (1972). Seven per cent acrylamide gels (AM-9 Cyanamide $\mathrm{B}-\mathrm{V}$, Rotterdam) in the Tris-glycine buffer $\mathrm{pH} 8.9$ are poured in the vertical water cooled gel apparatus (E.C. Apparatus Co. Philadelphia) and the same buffer circulated between the anode and cathode compartments. The gels are polymerized with ammonium persulphate and tetramethylethylenediamine. Twenty $\mu l$ of serum is layered into each slot and the voltage adjusted to give a current density of $75 \mathrm{~mA}$ per gel. 
After electrophoresis the gels are stained with Amido Black (2 per cent in methanol, acetic acid, water-9 $: 2: 9$ ) and destained in the same methanol, acetic acid, water mixture.

4. Preparation of samples. Transferrin is saturated with iron before electrophoresis by mixing equal volumes of serum and 0.15 per cent ferric ammonium sulphate in $0.005 \mathrm{M}$ Tris and two volumes of 10 per cent sucrose in $0.005 \mathrm{M}$ Tris containing a trace of Bromphenol Blue.

5. Determination of Relative Mobility. The method of Sutton and Jamieson (1972) is followed, using the Tris-glycine buffer $\mathrm{pH} 8.9$ for most comparisons and a Tris-borate buffer $\mathrm{pH} 6.5$ to check changes in mobility. $(12.5 \mathrm{~g}$ boric acid in 1 litre distilled water and adjusted with Tris to $\mathrm{pH}$ 6.5). Two samples of standard $\mathrm{CD}_{1}$ serum are included in each gel together with duplicate samples of the test material. Gels are run for varying periods of time (generally 2 to $6 \mathrm{hr}$ ) and the stained gels are photographed and enlarged approximately three times to facilitate accurate measurement of band spacing. The distance between the transferrin $\mathrm{C}$ and variant band is plotted against the distance between transferrin $C$ and $D_{1}$ and the Relative Mobility (R.M.) is determined from the slope of the line through the points plotted.

\section{RESULTS}

\section{Korean variants}

Six of the Korean variants had a slower migrating transferrin band in addition to the $\mathrm{C}$ band. Careful comparison using agarose gel electrophoresis showed them to be identical with each other in mobility, and all to be slightly faster than the standard $D_{1}$. One of these samples was selected for determination of Relative Mobility in the vertical polyacrylamide gel system. The R.M. at pH 8.9 is +0.90 and at $\mathrm{pH} 6.5$ is +0.96 . This is identical with the value for a standard $D_{\mathrm{Ch} 1}$ established in our laboratory, although slightly lower than the value of 0.93 given by Sutton (personal communication)

Three Korean variants had faster migrating bands, in addition to the $\mathrm{C}$ band, and two of these were identical with each other in the agarose gel system. R.M. values for these two different variants were determined in the polyacrylamide gel system. At pH 8.9 one had an R.M. $=-0.67$ and at $\mathrm{pH} 6.5$ it had an R.M. $=-0.92$. These values are almost identical with those given for $\mathrm{B}_{\mathrm{L}_{\mathrm{ambert}}}$ by Sutton. The other fast migrating Korean variant had an R.M. $=-1.14$ at $\mathrm{pH} 8.9$ and -0.77 at $\mathrm{pH} 6.5$. The value at $\mathrm{pH} 8.9$ is almost identical with that for $\mathrm{B}_{0-1}$ given by Sutton, but there is no information on the R.M. of $\mathrm{B}_{0-1}$ at $\mathrm{pH}$ 6.5.

\section{Japanese variants}

We have tested two Japanese variants having bands with a mobility slower than

C. In our agarose gel system these two variants are identical with the Korean slow variants and they have been designated $\mathrm{D}_{\mathrm{Chi}}$. 
Two Japanese variants had bands with mobility greater than $\mathrm{C}$, and they were not identical. In the polyacrylamide gel system one of these variants had a relative mobility of -1.33 at both $\mathrm{pH} 8.9$ and $\mathrm{pH} 6.5$. This is approximately midway between the R.M. values for $B_{0}$ and $B_{0-1}$. The other variant had an R.M. $=-0.75$ at $\mathrm{pH} 8.9$ and -0.84 at $\mathrm{pH}$ 6.5. At $\mathrm{pH} 8.9$ this value is almost identical with that shown by Sutton and Jamieson (1972) for $B_{\text {Seattle }}$ (alternative name $B_{M a t s u b u}$ ), but unlike our variant this has the same R.M. at pH 6.5.

\section{DISCUSSION}

The proof of identity of transferrin variants requires peptide mapping and, ultimately, complete sequencing of the polypeptide chain. In the absence of this information it is increasingly difficult to obtain samples from all described variants to enable direct mobility comparisons to be made. To overcome this difficulty Sutton's laboratory has suggested that Relative Mobility comparisons be made using at least two standard buffer systems in polyacrylamide gel (Sutton and Jamieson, 1972). The standard of comparison recommended is Transferrin $D_{1}$, which is readily available, of course, in the Americans, in African countries, and also in England,

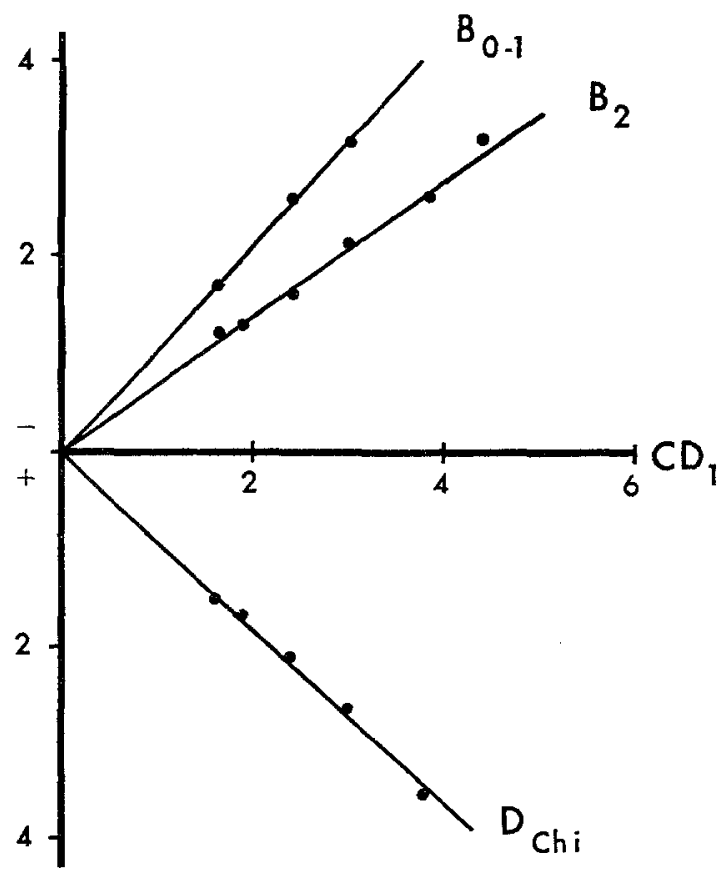

Fig. 1. Plots of mobility for three standard transferrin variants using thin layer agarose gel electrophoresis (TLAGE) pH 8.9 . 
Australia and New Guinea. In countries where $D_{1}$ is not readily available, such as Japan, it is easy to recalculate the relative mobilities against the $\mathrm{D}_{\mathrm{Ch} i}$ variant.

The vertical polyacrylamide gel electrophoretic (PAGE) system used by Sutton gives excellent results, but is also relatively expensive. To enable comparisons to be made more easily we have therefore compared results using this system with those using thin layer agarose gel electrophoresis (TLAGE). Our results with several standards (kindly supplied by Dr. Eldon Sutton) indicate that TLAGE can be used effectively at pH 8.9. Standard R.M.'s at pH 8.9 in the TLAGE system are shown in Fig. 1. In the present investigation we have used TLAGE to determine identical mobilities in comparisons between samples but we have used PAGE to determine relative mobilities.

Among the Korean and Japanese variants studied here we found only one type and this could not be distinguished from standard $D_{\mathrm{Chi}}$, either in the TLAGE system at $\mathrm{pH} 8.9$ or in PAGE at pH 8.9 and 6.5. This is in contrast to Ferrell et al. (1977) report of five different $D$ variants detected in just over 4,000 persons tested in Hiroshima and Nagasaki, although the commonest variant they found was also identified as $\mathrm{D}_{\mathrm{Chi}}$. In addition Ferrell et al. reported two persons with a $\mathrm{D}$ band faster than $D_{\mathrm{Ohi}}$, having an R.M. in the PAGE system the same as the standard $\mathrm{D}_{4}$ : since identical R.M. value does not prove identity they designated this Hiroshima variant $\mathrm{D}_{\mathrm{Hir}: 2}$. They found three persons with $\mathrm{D}_{\mathrm{Hir}: 3}$ with an R.M. corresponding to the standard $\mathrm{D}_{\mathrm{Ra} \text { if ord }}$ and one person with a variant $\mathrm{D}_{\mathrm{Hir:1}}$ which had a band close to $C$ on starch gel and with an R.M. similar to that of $D_{0}$. One other $D$ variant, designated $D_{\mathrm{Nagasaki}}$, found in a single individual was unusual in being indistinguishable from transferrin $C$ on starch gel, but slower in the PAGE system at pH 8.4. Finally, it is interesting to note that we did not find in Korea a type corresponding to $\mathrm{D}_{1}$, as reported by Shim (1964). $\mathrm{D}_{1}$ was also not found by Ferrell et al., but these authors found a variant $\left(D_{\mathrm{Hir}: 3}\right)$ with a migration very slightly more cathodal to $D_{1}$. It is possible that Shim's $D_{1}$ could have been $D_{\mathrm{Hir}: 3}$.

For the faster moving $\mathrm{B}$ variants our studies have detected four distinct variants. Two of these occur in Koreans and two in Japanese. Ferrell et al. found three different $B$ variants among the 4,020 persons tested in Hiroshima and Nagasaki. They found nine persons with a variant having the same R.M. as $B_{3}$, and one of our Japanese variants also had an R.M. corresponding to $\mathrm{B}_{3}$ at $\mathrm{pH} 8.9$, but with a higher value at $\mathrm{pH}$ 6.5. It is not clear whether our variant is $B_{3}$, and we have designated it $B_{J a p: 1}$. Ferrell et al. found 19 persons with a $B_{\mathrm{Hir}: 2}$, with a mobility between standard $\mathrm{B}_{1}$ and $B_{3}$, and they suggested this may be the same as the $B_{1}$ type reported by Omoto and Harada (1972) and Kudo and Ishimoto (1973), though they do not give R.M. values for their own variant. The designation $B_{1}$ by earlier Japanese workers is probably due to an erroneous standard $B_{1}$, which has an R.M. of -0.76 and is designated $B_{\text {Seattle }}$ or $M_{\text {Matsubu }}$ (Sutton and Jamieson, 1972; Sutton, personal communication). None of our B variants corresponded with this R.M.

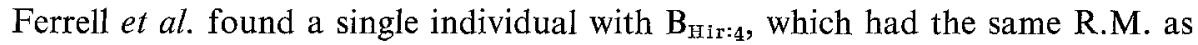




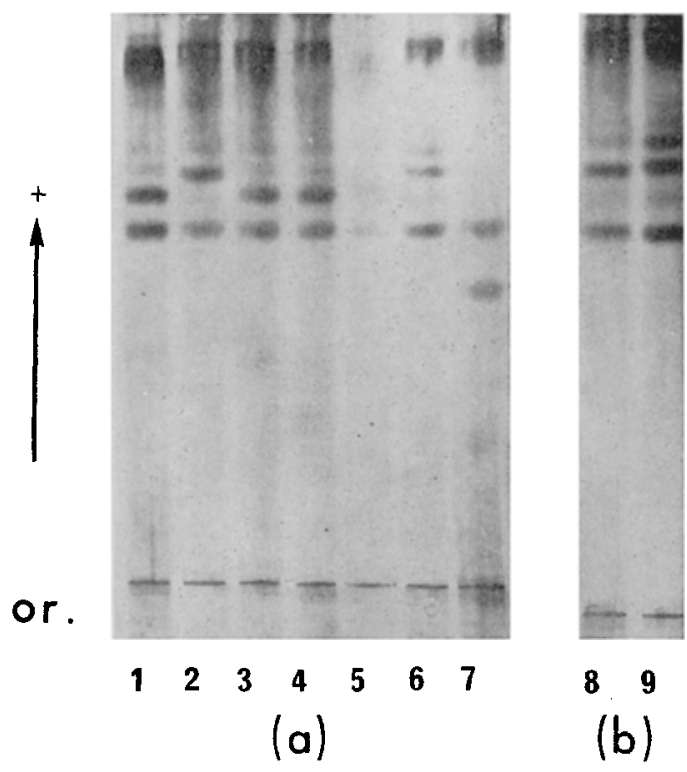

Fig. 2. Some fast-moving transferrin variants in Korea and Japan using the TLAGE system $\mathrm{pH} 8.9$. (a) 1, CBE orea 1 ; 2, CBKorea $2 ; 3$, CBKorea 1 ; 4, CBKorea 1 ; 5 , CBJap. $1 ; 6$, CBJap. $2 ; 7, \mathrm{CD}_{1}$. (b) $8, \mathrm{CB}_{\text {orea } 2} ; 9, \mathrm{CB}_{\text {Jap. } 2 .}$

Table 1. Transferrin variants in Korea and Japan.

\begin{tabular}{|c|c|c|c|c|c|}
\hline \multicolumn{2}{|c|}{$\begin{array}{l}\text { Relative positions at } \mathrm{pH} 8.4-9.1 \\
\text { on acrylamide gel }\end{array}$} & \multicolumn{2}{|c|}{ Relative mobility } & \multirow[t]{2}{*}{ Locality } & \multirow[t]{2}{*}{ Reference } \\
\hline $\begin{array}{l}\text { International } \\
\text { standard }\end{array}$ & $\begin{array}{l}\text { Japanese and Korean } \\
\text { variants }\end{array}$ & $\begin{array}{c}\mathrm{pH} \\
8.4-9.1\end{array}$ & $\mathrm{pH} 6.5$ & & \\
\hline $\begin{array}{l}\mathrm{B}_{0-1} \\
\mathrm{~B}_{1}\end{array}$ & 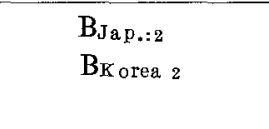 & $\begin{array}{l}-1.33 \\
-1.1 \\
-1.08\end{array}$ & $\begin{array}{l}-1.33 \\
-0.77 \\
-1.08\end{array}$ & & $\begin{array}{l}\text { This study } \\
\text { This study }\end{array}$ \\
\hline $\mathrm{B}_{\text {Lambert }}$ & $\begin{array}{l}\text { BKorea } 1 \\
\text { BHir:4 }\end{array}$ & $\begin{array}{l}-0.99 \\
-0.91\end{array}$ & $\begin{array}{l}-0.99 \\
-0.91\end{array}$ & Hiroshima & $\begin{array}{l}\text { This study } \\
\text { Ferrell } \text { et al. (1977) }\end{array}$ \\
\hline B $_{\text {Serttle(Matsubu) }}$ & $\begin{array}{l}\left(\mathrm{BHir}_{2}\right) \\
\left(\mathrm{B}_{\left.J_{\mathrm{ap}: 1}\right)}\right)\end{array}$ & $\begin{array}{l}-0.76 \\
-0.75\end{array}$ & $\begin{array}{l}-0.76 \\
-0.84\end{array}$ & Hiroshima & $\begin{array}{l}\text { Ferrell et al. }(1977) \\
\quad \text { This study }\end{array}$ \\
\hline $\mathrm{B}_{3}$ & & -0.62 & & $\begin{array}{l}\text { Present in many } \\
\text { Japanese }\end{array}$ & $\begin{array}{c}\text { Omoto (1975) } \\
\text { Ferrell et al. (1977) }\end{array}$ \\
\hline \multicolumn{6}{|l|}{$\mathrm{C}$} \\
\hline & $D_{N G S: 1}$ & & & Nagasaki & Ferrell et al. (1977) \\
\hline & $\mathrm{D}_{\text {Hir }: 1}$ & & & Hiroshima & Ferrell et al. (1977) \\
\hline$D_{4}\left(D_{0-1}\right)$ & $\mathrm{D}_{\mathrm{Hir}: 2}$ & 0.76 & & Hiroshima & Ferrell et al. (1977) \\
\hline Dohi & & 0.90 & 0.91 & $\begin{array}{l}\text { Probably present } \\
\text { in all Japanese } \\
\text { and Korean } \\
\text { pop'ns }\end{array}$ & $\begin{array}{l}\text { Omoto (1975) } \\
\text { Ferrell } \text { et al. (1977) } \\
\text { This study }\end{array}$ \\
\hline$D_{1}$ & & 1.00 & 1.00 & Korea? & Shim (1964) \\
\hline Dra iford & $D_{H i r: 3}$ & 1.05 & 1.05 & Hiroshima & Ferrell et al. (1977) \\
\hline
\end{tabular}


standard $\mathrm{B}_{\mathrm{Lambert}}$ at $\mathrm{pH} 6.5$, but unlike $\mathrm{B}_{\mathrm{Lambert}}$, its R.M. was unchanged at $\mathrm{pH} 8.8$. In our own series, however, one of our Korean variants had R.M.'s of -0.67 at $\mathrm{pH}$ 8.9 and -0.92 at $\mathrm{pH} 6.5$, which are almost identical with the value for $\mathrm{B}_{\mathrm{Lambert}}$ at

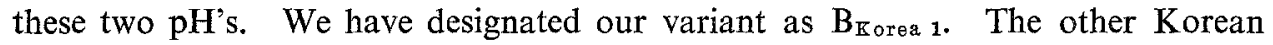
variant, $\mathrm{B}_{\text {K } \text { orea } 2}$, is very fast at $\mathrm{pH} 8.9$, corresponding to standard $\mathrm{B}_{0-1}$. However, we found an R.M. of -0.77 at $\mathrm{pH} 6.5$ and we have no information on $\mathrm{B}_{0-1}$ at this $\mathrm{pH}$. Our other Japanese variant has been designated $B_{J a p: 2}$, with an R.M. of -1.33 at $\mathrm{pH} 8.9$ and $\mathrm{pH} 6.5$. This variant seems to be quite distinct from any previously described in the literature and by Ferrell et al. (1977). Our new variants are displayed using the TLAGE system in Fig. 2.

It is clear that careful study of Japanese and their neighboring Koreans displays an unusual amount of variation at the transferrin locus. $\mathrm{CD}_{\mathrm{ChI}}$ is polymorphic in most populations surveyed so far, totalling nearly 20,000 persons. At least two of the $B$ variants occur relatively frequently in several surveys and a number of others have been detected either singly or in a few persons. Table 1 summarizes the present information.

What is important is the need for careful comparison of variants in further surveys. Our present contribution is to indicate the usefulness of comparisons made by the TLAGE system and also to stress that R.M.'s at two pH's, preferably about pH 9.0 and 6.5, should be reported for each variant described.

Acknowledgements We are indebted very much to the excellent technical and clerical assistance of Ms. Christine Hayes and Ms. Elizabeth Robertson. Our thanks are due also to Dr. Eldon Sutton for helpful discussions and information.

\section{REFERENCES}

Ferrell, R. E., Ueda, N., Satoh, C., Tanis, R. J., Neel, J. V., Hamilton, H. B., Inamizu, T. and Baba, K. 1977. The frequency in Japanese of genetic variants of 22 proteins: 1. Albumin, ceruloplasmin, haptoglobin, and transferrin. Ann. Hum. Genet. 40: 407-418.

Giblett, E. R. 1969. Genetic Markers in Human Blood. Blackwell Scientific, Oxford.

Harris, H., Robson, E. B. and Siniscalco, M. 1958. " $\beta$-Globulin" variants in man. Nature 182: 452.

Kirk, R. L. 1968. The world distribution of transferrin variants and some unsolved problems. Acta Genet. Med. Gemell. 17: 613-640.

Kudo, T. and Ishimoto, G. 1973. A case of a rare type of serum transferrin. Jap. J. Legal Med. 27: 447 .

Omoto, K. 1975. Serum protein groups. In Distribution of Polymorphic Traits in the Japanese and Neighboring Populations. JIBP Synthesis Vol. 2. University of Tokyo Press. pp. 141162.

Omoto, K. and Harada, S. 1972. The distribution of polymorphic traits in the Hidaka Ainu. II. Red cell enzyme and serum protein groups. J. Fac. Sci. Uni. Tokyo (VI) 4 (2): 171-211.

Parker, W. C. and Bearn, A. G. 1961. Haptoglobin and transferrin variation in human and primates: two new transferrins in Chinese and Japanese populations. Ann. Hum. Genet. 25: 227-241.

Shim, B. S. 1964. Occurrence of transferrin $D_{1}$ in Korea. Nature 203: 432.

Sutton, H. E. and Jamieson, G. A. 1972. Transferrin, haptoglobin and ceruloplasmin. In The Glycoproteins (Ed. A. Gottschalk) 2nd Ed. Elsevier, Amsterdam. p. 653. 